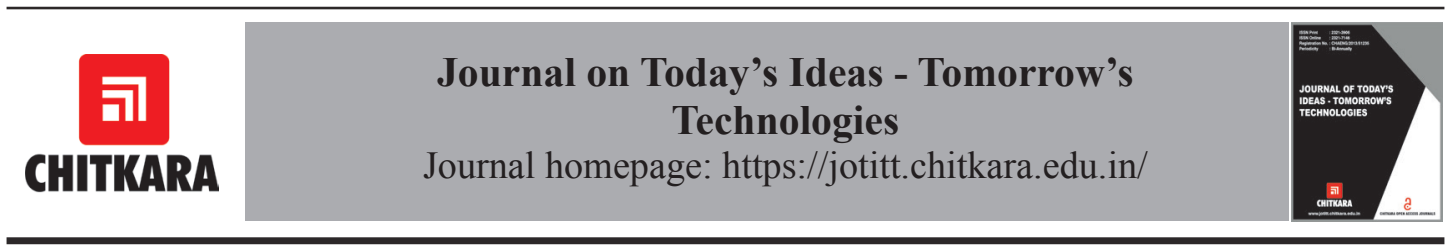

\title{
An Experimental Study on Ground Improvement by Application of Fly Ash and Lime on Clayey and Sandy Soil
}

\author{
Pinak Ray $^{1 *}$, Subham Roy ${ }^{2}$, Alekhya Sarkar ${ }^{3}$ \\ ${ }^{1,3}$ Techno India University, West Bengal - 700091, India. \\ ${ }^{2}$ University of Engineering and Management, West Bengal- 410506, India.
}

Email: pinak.r@technoindiaeducation.com, pinakray2@gmail.com*

\section{ARTICLE INFORMATION}

Received: June 08, 2019

Revised: August 15, 2019

Accepted: September 13, 2019

Published online: December 30, 2019

\section{Keywords:}

Clayey soil, Sand, Lime, Fly ash, Hydraulic Conductivity, Maximum Dry Density, Shear Strength, CBR test.

\begin{abstract}
Construction on locally available clayey soil is often problematic due to its swelling and shrinkage nature. Pavements are most affected as the up thrust due to regional swelling of clayey soil during monsoon season and shrinking during dry season causes unwanted cracks in the pavement. As a consequence the pavement gets damaged. In places having extensive deposit of clayey soil, soil replacement becomes time consuming and uneconomical. Hence the clayey soil to be considered as subgrade needs to be pre-treated. Fly ash, an industrial waste can be used for such treatment. To improve the engineering properties of on-site available clayey soil and sandy soil with lime and fly ash was studied. Based on the results obtained from experiments the suitability of fly ash and lime to be considered as additives to improve local clayey and sandy soil properties has been analyzed. It was observed that the on addition of fly ash within $40-60 \%$ range can be satisfactorily used to replace the local clayey soil and fly ash percentage within $20-40 \%$ can be used to replace the local sand. Lime content in the range of $4-8 \%$ can be satisfactorily used in both in situ available soil and local sand with fly ash mixtures for the improvement of strength in terms of shear strength as well as CBR value.
\end{abstract}

\section{Introduction}

Properties of soil subgrade always take a paramount role in the behaviour of the pavement. The durability and stress acting on various layers of the pavement depends on the nature of the subgrade. Cohesion (c), angle of internal friction $(\phi)$, resilient modulus $\left(\mathrm{M}_{\mathrm{R}}\right)$ and California Bearing
Ratio (CBR) values of subgrade materials determine its mechanical properties [1]. Decrease in the availability of conventional constructional materials such as aggregates and sand has caused an increase in price which has led to demand of suitable cheaply available alternative materials like industrial and domestic waste products 
that can be taken as replacement. Fly ash produced in thermal power plant is disposed as a waste by-product can be used as a suitable soil stabilizing material. Enhanced engineering characteristics of soil by mixing fly ash can be used to construct roads and safely reuse the waste material. Fly ash is produced by burning of coal in electric utility or industrial boilers. Experiments on specimens with varied proportions of sand, lime, fly ash and locally available clay has been conducted and correlations between the engineering properties i.e. cohesion, angle of friction, CBR and hydraulic conductivity has been established in this present study. The study has performed detailed laboratory analysis on the consequences of application of varying percentage of stabilizer and waste material on locally available soil and sand in order to observe the variation in shear strength; maximum dry density; hydraulic conductivity, and CBR values.

\section{Review of Literature}

Addition of fly ashes of Class $\mathrm{C}$ and Class $\mathrm{F}$ showed increase in CBR properties of the Black Cotton Soil [2]. Tests were carried out which indicate that time for curing, condition of curing, clay mineral composition, amount of fly ash and potential of swelling in the soil-fly ash mix as the important variables controlling stabilization characteristics [3]. Various studies showed decreased optimum moisture content (OMC) and maximum dry density (MDD), increased unconfined compression strength (UCS), deviator stress, California Bearing Ratio (CBR) with increase in fiber content till a certain percentage with poor graded fine sand as a result of influence of reinforced class $\mathrm{F}$ fly ash properties through dynamic and static load tests and semi field tests [4]. Lime stabilization affected the durability and strength aspects of pond ash class $\mathrm{F}$, with a lime percentage as low as 1.12, have been reported [5]. It has been obtained maximum value of 5.6 CBR for $12 \%$ lime and $40 \%$ flyash mixed with black cotton soil [6]. Various tests on different ratios of Sand and Fly ash mixtures showed slight decrease in permeability of compacted coal ash sand mixtures with increased fly ash percentage, CBR value decreased for both unsoaked and soaked condition [7]. Maximum dry density (MDD) of sand-clay-fly ash mix decreased with the increase in fly ash and optimum moisture content (OMC) increased, the California bearing ratio $(\mathrm{CBR})$ of the stabilized clay increased from $2.47 \%$ to $4.56 \%$ for soaked CBR and $5.59 \%$ to $7.36 \%$ for unsoaked C.B.R [8].Various laboratory tests have been conducted to observe the effect of natural pozzolana, lime or a combination of both on the geotechnical characteristics of cohesive soils, maximum dry density (MDD) of lime stabilized soils decreased with increase in lime content, in comparison with natural pozzolana stabilized soils, the optimum moisture content (OMC) of lime stabilized soils showed increase with increase in lime content, in comparison with natural pozzolana stabilized soils, increased curing time resulted in increased shear strength for both lime stabilized cohesive soils stabilized or with the combination of lime-natural pozzolana [9]. Laboratory tests have been conducted to study how lime content affected compaction characteristics and CBR values of flyash when subjected to different compaction energies; addition of lime increased the maximum dry density (MDD) and decreased optimum moisture content [10]. From coal burning electric utilities byproducts of Class $\mathrm{F}$ fly ash and bottom ash have used in different ratios with conventional granular materials. It has been observed that if proper design and construction procedures can be followed high volume fly ash mixtures can be used as very good admixtures for construc- 
tion of highway embankments [11]. To determine effectiveness of self-cementing fly ashes which are obtained from combustion of sub-bituminous coal at electric power plants to stabilize soft fine-grained soils, experimental study has been conducted by preparing soil-fly ash mixtures at different fly ash contents i.e. 10 to $30 \%$. For wet and soft finegrained subgrade soils how addition of fly ash can develop the California bearing ratio $(\mathrm{CBR})$ and resilient modulus $\left(\mathrm{M}_{\mathrm{r}}\right)$ of the soil has been evaluated [12].For stabilization and improvement of organic soils the effectiveness of use of fly ash has been studied. It has been observed that with increase in organic content of soil exponential decrease of shear strength of the soil-fly ash mixture has been found. In addition to this, increase of unconfined compressive strength and resilient modulus has been observed when there was an increase of fly ash percentage [13].

\section{Materials}

Local soil collected from Garia, Kolkata (West Bengal) for investigation. Visually the soil was identified as light grey silty clay. The properties of the soil as obtained from laboratory analysis are summarized in Table 1.

Table 1: Index and engineering properties of clay

\begin{tabular}{|c|c|c|c|}
\hline $\begin{array}{l}\text { S. } \\
\text { No. }\end{array}$ & \multicolumn{2}{|c|}{ Properties } & Value \\
\hline 1 & \multicolumn{2}{|c|}{ Specific Gravity } & 2.53 \\
\hline \multirow[t]{3}{*}{2} & \multirow{3}{*}{$\begin{array}{l}\text { Particle Size } \\
\text { Distribution } \\
(\%)\end{array}$} & Sand & $\mathrm{O}$ \\
\hline & & Silt & 45 \\
\hline & & Clay $(<75 \mu)$ & 55 \\
\hline 3 & \multicolumn{2}{|c|}{ Liquid Limit (\%) } & 41 \\
\hline 4 & \multicolumn{2}{|c|}{ Plastic limit (\%) } & 22.8 \\
\hline 5 & \multicolumn{2}{|c|}{ Plasticity Index (\%) } & 18.2 \\
\hline 6 & \multicolumn{3}{|c|}{$\begin{array}{l}\text { Soil has been classified as } \mathrm{CH} \text { and } \\
\text { visually Light grey silty clay }\end{array}$} \\
\hline
\end{tabular}

Locally available sand of medium to coarse grain was used. Detailed engineering properties have been given in the Table 2 .

Table 2: Index and engineering properties of sand

\begin{tabular}{|l|l|c|c|}
\hline $\begin{array}{l}\text { S. } \\
\text { No. }\end{array}$ & \multicolumn{2}{|c|}{ Properties } & Value \\
\hline 1 & \multicolumn{2}{|l|}{ Specific Gravity } & 2.63 \\
\hline 2 & \begin{tabular}{l} 
Particle Size \\
Distribution \\
\cline { 2 - 3 }
\end{tabular}$\%$ & Sand & 100 \\
\cline { 2 - 4 } & Silt & Clay & 0 \\
\hline 3 & \multicolumn{2}{|l|}{$\begin{array}{l}\text { Uniformity coeffi- } \\
\text { cient, } \mathrm{C}_{\mathrm{u}}\end{array}$} & 3.8 \\
\hline 4 & \multicolumn{2}{|l|}{$\begin{array}{l}\text { Coefficient of curva- } \\
\text { ture, } \mathrm{C}_{\mathrm{c}}\end{array}$} & 0.7 \\
\hline 5 & \multicolumn{2}{|l|}{$\begin{array}{l}\text { Sand has been classified as poorly } \\
\text { graded medium coarse sand (SP) }\end{array}$} \\
\hline
\end{tabular}

Fly ash used for the experiment was collected from National Thermal Power Corporation Limited (NTPC), Farakka (West Bengal, India). The engineering properties have been evaluated and have been shown in Table 3 . Pipette method was conducted over the fly ash for characterization of grain size distribution.

Table 3: Index and engineering properties of fly ash

\begin{tabular}{|c|l|c|c|}
\hline $\begin{array}{c}\text { S. } \\
\text { No. }\end{array}$ & \multicolumn{2}{|c|}{ Properties } & Value \\
\hline 1 & Color & $\begin{array}{c}\text { Light } \\
\text { Grey }\end{array}$ \\
\hline 2 & \multicolumn{2}{|l|}{ Specific Gravity } & 2.4 \\
\hline 3 & \begin{tabular}{l} 
Particle Size \\
Distribution \\
\cline { 2 - 3 }$(\%)$
\end{tabular} & Sand & 6.5 \\
\cline { 2 - 4 } & Silt & 89.6 \\
\hline 4 & \multicolumn{2}{|l|}{ Liquid Limit (\%) } & 3.9 \\
\hline 5 & \multicolumn{2}{|l|}{ Plastic Limit (\%) } & 53 \\
\hline
\end{tabular}

ISSN No.: 2321-3906 (Print) ISSN No.: 2321-7146 (Online) Registration No.: CHAENG/201/51235 Periodicity: Bi-Annually 


\begin{tabular}{|c|l|c|}
\hline \multicolumn{3}{|c|}{ Table 3 [continued] } \\
\hline 6 & Plasticity Index (\%) & Non Plastic \\
\hline 7 & Free swell index (FSI) & $\begin{array}{c}\text { Non-swell- } \\
\text { ing }\end{array}$ \\
\hline
\end{tabular}

The typical properties of hydrated lime as obtained from Adelaide Brighton Cement Ltd.have been summarized in Table 4 and Table 5 respectively.

Table 4: Physical properties of lime

\begin{tabular}{|l|l|}
\hline Fineness & $\begin{array}{l}\text { O.1\% of total weight of } \\
\text { lime retained on a 75 mi- } \\
\text { cron sieve and less than } \\
\text { O.05\% on 250 micron } \\
\text { sieve. }\end{array}$ \\
\hline Specific Gravity & \multicolumn{1}{|c|}{$2.2-2.3$} \\
\hline Bulk Density & $400-600 \mathrm{~kg} / \mathrm{m}^{3}$ \\
\hline
\end{tabular}

Table 5: Chemical composition of lime

\begin{tabular}{|l|c|c|}
\hline $\begin{array}{l}\text { S. } \\
\text { No. }\end{array}$ & Oxide & $\begin{array}{c}\text { Typical analyses } \\
(\%)\end{array}$ \\
\hline 1 & $\mathrm{SiO}_{2}$ & 1.8 \\
\hline 2 & $\mathrm{Al}_{2} \mathrm{O}_{3}$ & 0.5 \\
\hline
\end{tabular}

\begin{tabular}{|l|c|c|}
\hline 3 & $\mathrm{Fe}_{2} \mathrm{O}_{3}$ & 0.6 \\
\hline 4 & $\mathrm{CaO}$ & 72 \\
\hline 5 & $\mathrm{MgO}$ & 1 \\
\hline 6 & Loss on ignition & 24 \\
\hline 7 & $\mathrm{CO}_{2}$ & 2.5 \\
\hline
\end{tabular}

Fig. 1 shows the comparison of grain size distribution curves between locally available clayey soil, local sand and fly ash respectively. Pipette method was conducted over the fly ash for the identification of grain size distribution and the curves are plotted respectively as shown in Fig. 1. Pipette method was conducted over the clayey soil for the determination of grain size distribution and the curves are plotted respectively as shown in Fig. 1. The grain size distribution of sand was determined using sieve analysis and the curves are plotted respectively as shown in Fig. 1. From the graph the uniformity coefficient $\left(\mathrm{C}_{\mathrm{u}}\right)$ for sand was calculated as $3.8(<6)$ and coefficient of curvature $\left(\mathrm{C}_{\mathrm{c}}\right)$ as $0.7(<1)$, therefore the soil has been classified as poorly graded sand (SP).

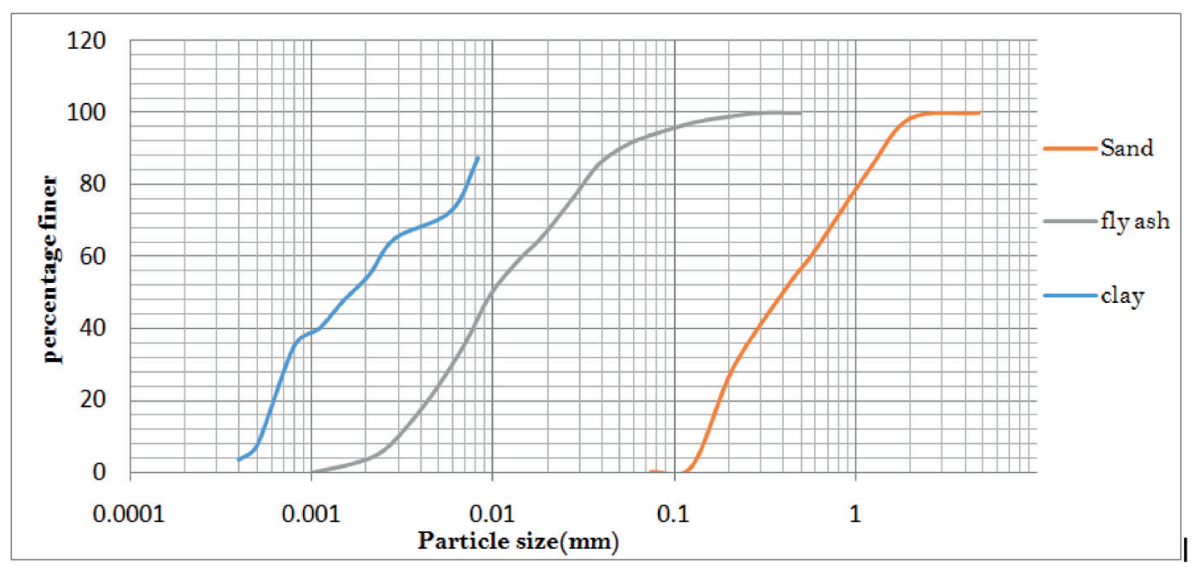

Figure 1: Grain size distribution of fly ash, clay and sand 


\section{Test Program}

Laboratory experiments was conducted to determine shear strength parameters, compaction characteristics, hydraulic conductivity and CBR value of locally available soil, sand mixes with different proportions of fly ash with or without chemical stabilizer lime in a view to get a rough estimate of optimum proportioning required so that the mix has sufficient strength to be used as a subgrade or sub-base. 17 nos. of specimens with varying proportions of sand, clay, fly ash and 6 specimens of sand, clay, fly ash with addition of lime content varying between 4 to $12 \%$ and one specimen having $70 \%$ sand and $30 \%$ fly ash and one specimen having $50 \%$ clay and 50\% fly ash were tested. Detailed mix proportions of the samples have been shown in Table 6 and Table 7 .

Table 6: Detailed mix proportions of clay, sand and fly ash (without lime stabilizer)

\begin{tabular}{|c|c|c|c|}
\hline S. No. & Clay (\%) & Sand (\%) & Fly ash (\%) \\
\hline 1 & $\mathrm{O}$ & 100 & $\mathrm{O}$ \\
\hline 2 & $\mathrm{O}$ & 0 & 100 \\
\hline 3 & $\mathrm{O}$ & 10 & 90 \\
\hline 4 & 0 & 20 & 80 \\
\hline 5 & $\mathrm{O}$ & 30 & 70 \\
\hline 6 & $\mathrm{O}$ & 40 & 60 \\
\hline 7 & $\mathrm{O}$ & 50 & 50 \\
\hline 8 & $\mathrm{O}$ & 60 & 40 \\
\hline 9 & $\mathrm{O}$ & 80 & 20 \\
\hline 10 & 100 & $\mathrm{O}$ & $\mathrm{O}$ \\
\hline 11 & 90 & $\mathrm{O}$ & 10 \\
\hline 12 & 80 & $\mathrm{O}$ & 20 \\
\hline 13 & 70 & $\mathrm{O}$ & 30 \\
\hline 14 & 60 & $\mathrm{O}$ & 40 \\
\hline 15 & 50 & $\mathrm{O}$ & 50 \\
\hline 16 & 35 & $\mathrm{O}$ & 65 \\
\hline 17 & 20 & $\mathrm{O}$ & 80 \\
\hline
\end{tabular}

Table 7: Detailed mix proportions of clay, sand and fly ash (with lime stabilizer)

\begin{tabular}{|c|c|c|c|c|}
\hline $\begin{array}{c}\text { S. } \\
\text { No. }\end{array}$ & $\begin{array}{c}\text { Clay } \\
(\%)\end{array}$ & $\begin{array}{c}\text { Sand } \\
(\%)\end{array}$ & $\begin{array}{c}\text { Fly ash } \\
(\%)\end{array}$ & $\begin{array}{c}\text { Lime } \\
(\%)\end{array}$ \\
\hline 18 & 48 & 0 & 48 & 4 \\
\hline 19 & 46 & 0 & 46 & 8 \\
\hline 20 & 44 & 0 & 44 & 12 \\
\hline 21 & 0 & 67.2 & 28.8 & 4 \\
\hline 22 & 0 & 64.4 & 27.6 & 8 \\
\hline 23 & 0 & 61.6 & 26.4 & 12 \\
\hline 24 & 0 & 70 & 30 & 0 \\
\hline 25 & 50 & 0 & 50 & 0 \\
\hline
\end{tabular}

\section{Test Procedure}

The test procedures were carried out as per the procedures mentioned in the IS code of practice and has been presented in Table 8 .

Table 8: Name of the tests performed and relevant IS code followed

\begin{tabular}{|c|l|l|}
\hline $\begin{array}{c}\text { S. } \\
\text { No. }\end{array}$ & \multicolumn{1}{|c|}{ Name of Test } & \multicolumn{1}{|c|}{$\begin{array}{c}\text { Name of IS } \\
\text { code followed }\end{array}$} \\
\hline 1 & $\begin{array}{l}\text { Classification and } \\
\text { Identification of } \\
\text { soil }\end{array}$ & $\begin{array}{l}\text { IS : 1498,1970 } \\
{[14]}\end{array}$ \\
\hline 2 & Specific Gravity & $\begin{array}{l}\text { IS : 2720, Part- } \\
\text { III, 1980 [15,16] }\end{array}$ \\
\hline 3 & $\begin{array}{l}\text { Grain size } \\
\text { analysis }\end{array}$ & $\begin{array}{l}\text { IS : 2720, Part- } \\
\text { IV,1985 [17] }\end{array}$ \\
\hline 4 & $\begin{array}{l}\text { Atterberg Limits } \\
\text { IS : 2720, Part } \\
- \text { V,1985 [18] }\end{array}$ \\
\hline 5 & $\begin{array}{l}\text { Standard Proctor } \\
\text { IS: 2720, Part- } \\
\text { VII,1980 [19] }\end{array}$ \\
\hline 6 & $\begin{array}{l}\text { Unconsolidated } \\
\text { Undrained Triaxi- } \\
\text { al }\end{array}$ & $\begin{array}{l}\text { IS : 2720, Part- } \\
\text { XI, 1993 [20] }\end{array}$ \\
\hline 7 & $\begin{array}{l}\text { California Bearing } \\
\text { Ratio }\end{array}$ & $\begin{array}{l}\text { IS :2720, Part- } \\
\text { XVI,1987 [21] }\end{array}$ \\
\hline 8 & $\begin{array}{l}\text { Hydraulic Con- } \\
\text { ductivity Test }\end{array}$ & $\begin{array}{l}\text { IS 2720, Part- } \\
\text { XVII, 1986 [22 }]\end{array}$ \\
\hline
\end{tabular}


The test specimens were prepared by adding different ratios of lime and fly ash with locally available soil and local sand and kept separately in poly bags. For determining of optimum moisture content (OMC) and maximum dry density (MDD); required amount of sample was taken out and Standard Proctor test has been performed.

For Unconsolidated Undrained Triaxial tests, the samples were prepared by first compacting the specimen at its OMC $+2 \%$ of moisture content, determined by Standard Proctor test and then extracted from the mould using three sampling tubes of $38 \mathrm{~mm}$ diameter with the help of hydraulic jack.

For CBR tests, CBR moulds were used to prepare the specimens as per the standard practice and was compacted to get moisture content equal to $\mathrm{OMC}+2 \%$ of water content, obtained from Proctor Test. As soon as the specimen was prepared, it was submerged under water for four days and weight was added.

\section{Results and Discussion}

\subsection{Standard proctor test results}

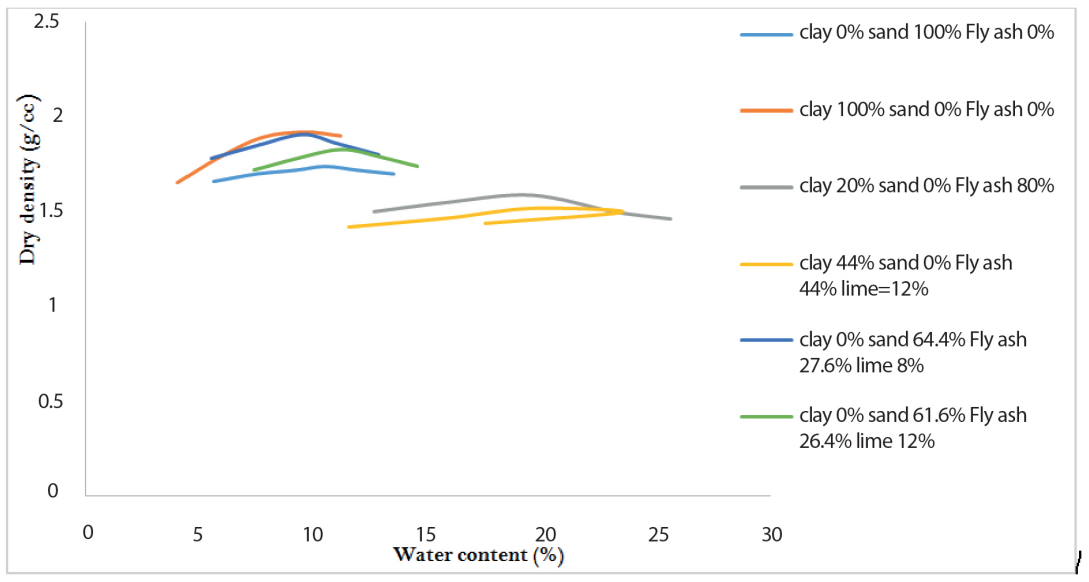

Figure 2: Standard proctor test results for few samples

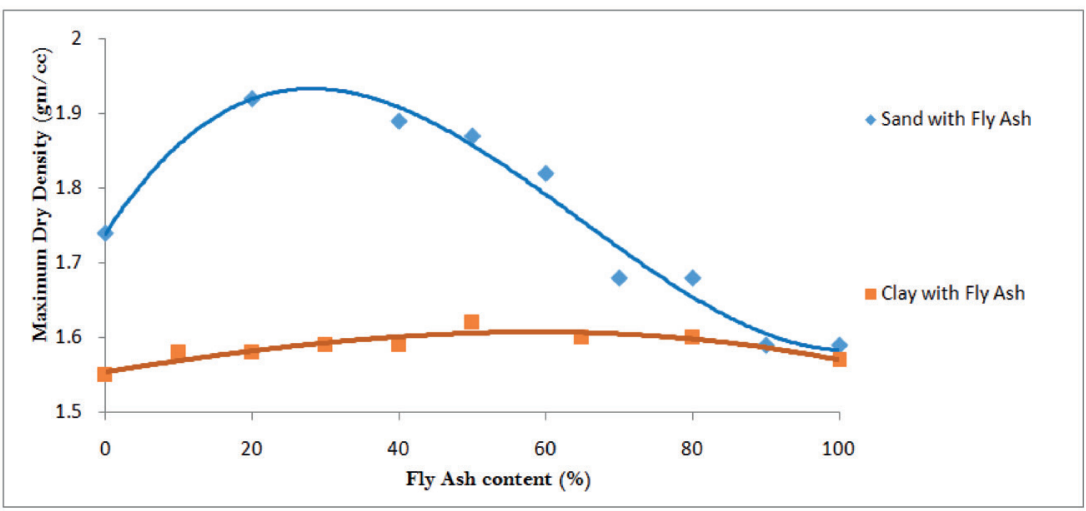

Figure 3: Variation of MDD with fly ash content for both sand and clay 
The Proctor compaction tests were carried out as per IS: 2720, Part-VII, 1980 on respective samples, the results obtained have been shown in Fig. 2. It was observed that with addition of fly ash the MDD increased whereas the OMC decreased up to maximum range for $20-40 \%$ of fly ash content. From the experimental results it has been observed that the sudden increment of maximum dry density value was caused due to better packing of sand and fly ash up to $20-40 \%$ as the fly ash fills most of the voids present. In Fig. 3 it has been observed that at for sand samples with $25 \%$ fly ash gives the maximum result of MDD, whereas for clay samples with $50 \%$ of fly ash content gives the maximum value of MDD. However, with further increase in fly ash content the MDD decreased and OMC increased as fly ash particles are finer than sand particles, thereby having more surface area and hence required more moisture to obtain the MDD. It has been obtained from further studies that MDD decreased and OMC increased with increased lime content. This kind of be- haviour may have occurred due to the specific gravity of lime is lower than thatof soil tested, and the pozzolanic action between the soil particles and lime resulted in an increase of OMC.

\subsection{Hydraulic conductivity test}

Series of hydraulic conductivity tests were performed as per IS 2720 (part 17) with varied percentage of fly ash percentage by weight. Some typical results have been provided in Fig. 4 which shows that at $25 \%$ of fly ash-sand mixture gives minimum value of coefficient of permeability, $\mathrm{k}(\mathrm{cm} / \mathrm{s})$ and at $50 \%$ of fly ash added with clay gives the minimum value of coefficient of permeability, $k$ $(\mathrm{cm} / \mathrm{s})$. But it is evident that rate of decrease of hydraulic conductivity is much higher in sand with respect to clay. For both the cases in sand + fly ash and clay + fly ash, for that specific content of fly ash where dry density was maximum it has been found that hydraulic conductivity was minimum.

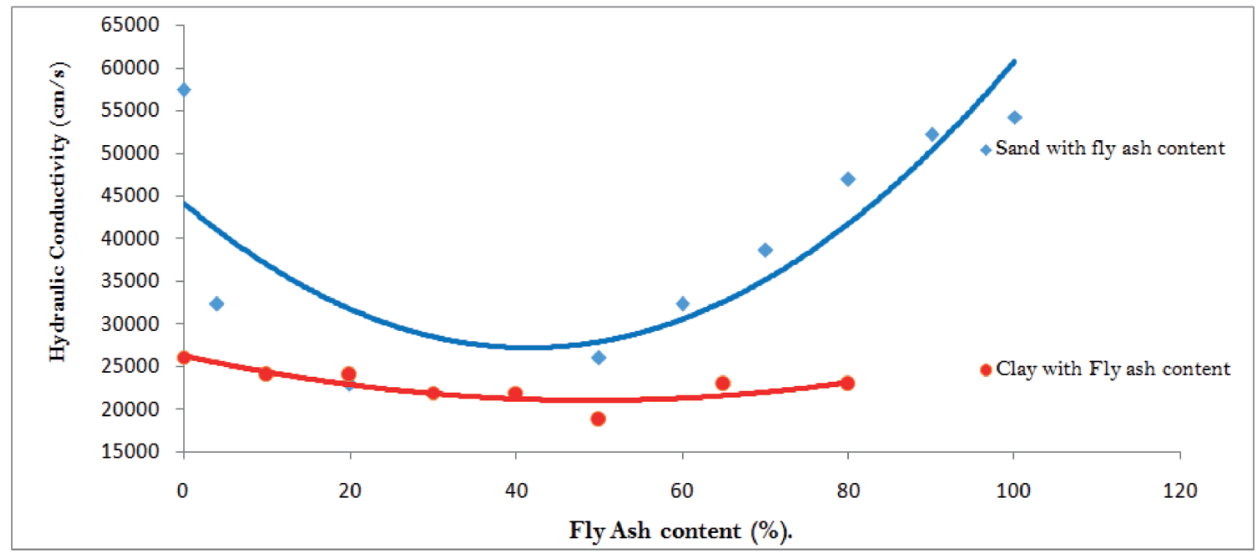

Figure 4: Variation of hydraulic conductivity with fly ash content. 


\subsection{Correlation between maximum dry density and hydraulic conductivity}

A series of proctor test have been performed by changing percentage of fly ash content with sand and with clay. After each proctor test the soil sample has been prepared in the permeability mould at the calculated MDD and at calculated OMC value from proctor test results. Then coefficient of permeability (in $\mathrm{cm} / \mathrm{s}$ ) of the soil mixture has been determined by permeability test. A correlation between $\mathrm{k}(\mathrm{m} / \mathrm{s})$ and MDD $\left(\mathrm{kN} / \mathrm{m}^{3}\right)$ has been obtained for both sandy and clayey soils by changing percentage of fly ash content. It has been found that hydraulic conductivity varies with MDD in exponentially. The correlation between $\mathrm{k}(\mathrm{m} / \mathrm{s})$ with MDD $\left(\mathrm{kN} / \mathrm{m}^{3}\right)$ for sandy soil has been found as:

$$
k=20771 \times e^{-(0.22 \times M D D)}
$$

For clayey soil:

$$
k=17679 \times e^{-(0.41 \times M D D)}
$$

The $\mathrm{R}^{2}$ value for this equation (1) and (2) have been found as 0.748 and 0.792 respectively which is quite acceptable in pavement construction.

\subsection{Unconsolidated undrained triaxial test}

Unconsolidated undrained triaxial tests (UU) were carried out as per I.S. $2720-11$ on $70 \%$ sand $+30 \%$ fly ash mixtures with varied lime proportion and following results yielded: cohesion and angle of friction gradually decreased due to increase in lime content as shown in Fig. 5 (a). The reason might be as the specific gravity of lime being less than that of sand and fly ash, thereby affecting its grading. Similarly both unsoaked and soaked (for 3 days) experiments carried out on $50 \%$ clay $+50 \%$ fly ash mixtures with a varying lime content and following results were yielded: for unsoaked condition the cohesion showed increase with increase of lime content and angle of friction decreased gradually, while for soaked condition the cohesion increased gradually with an increase in lime content, whereas the angle of friction first increased up to a maximum value at about $6-8 \%$ lime content and thereafter it decreased as showed in Fig. 5 (b). Shear strength of soil samples under soaked condition were greater than that of unsoaked condition in addition of lime because lime acts as a stabilizer and a pozzolanic reaction takes in presence of water and thus the strength showed increase with increase in curing time. Shear strength under soaked condition at $4 \%$ lime increased about 1.38 times than that of unsoaked condition, whereas it increased about 1.44 times at $12 \%$ lime content.

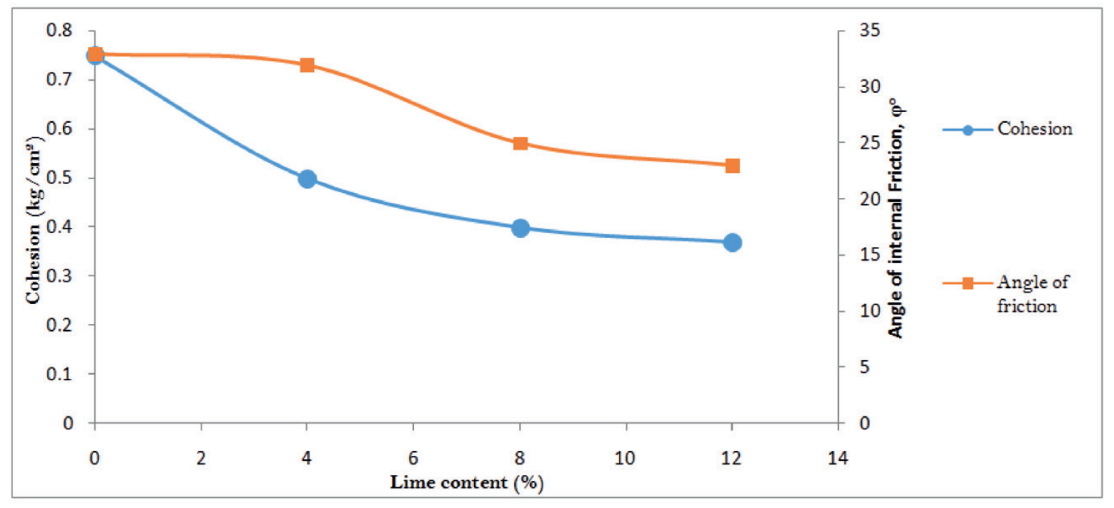

(a)

ISSN No.: 2321-3906 (Print) ISSN No.: 2321-7146 (Online) Registration No.: CHAENG/2013/51235 Periodicity: Bi-Annually 


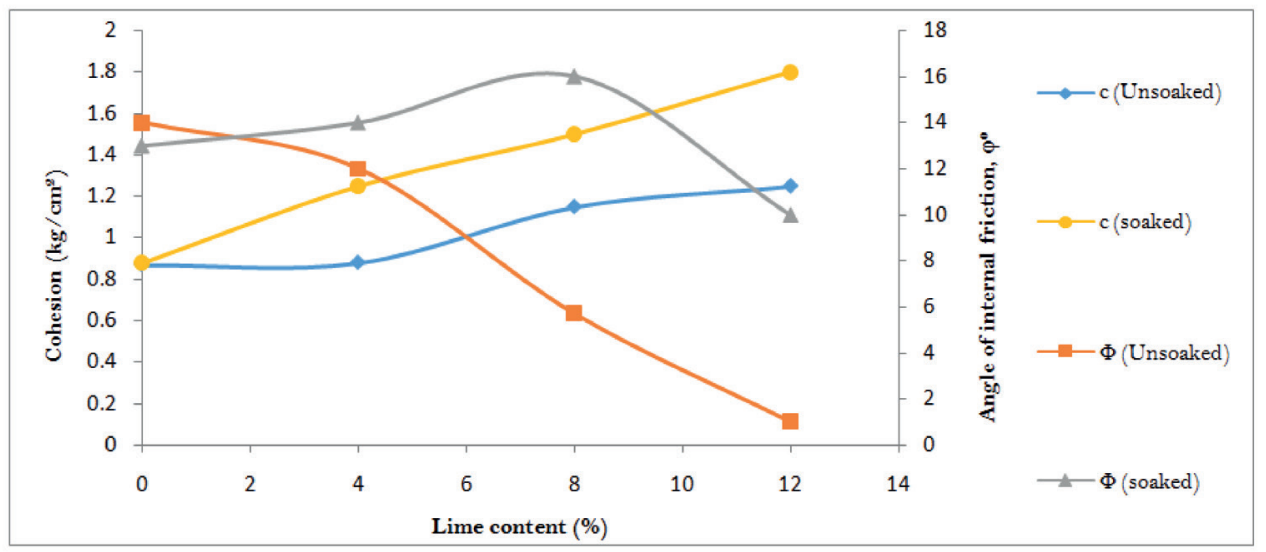

(b)

Figure 5: Variation of $\mathrm{c}$ and $\phi$ of (a) $70 \%$ sand $+30 \%$ fly ash and (b) $50 \%$ clay $+50 \%$ fly ash with lime content

\subsection{Soaked CBR test}

Soaked C.B.R tests were carried out as per I.S. 2720 part 16 on the mixtures of $(70 \%$ sand $+30 \%$ fly ash) and (50\% clay $+50 \%$ fly ash) with varying lime content, it yielded the following results: the CBR values in both cases increased drastically in addition of lime up to a maximum range of 5 to $6 \%$ as shown in Fig. 6. The reason behind such change is that a cementing action took place in presence of water which in turn increased the load carrying capacity.

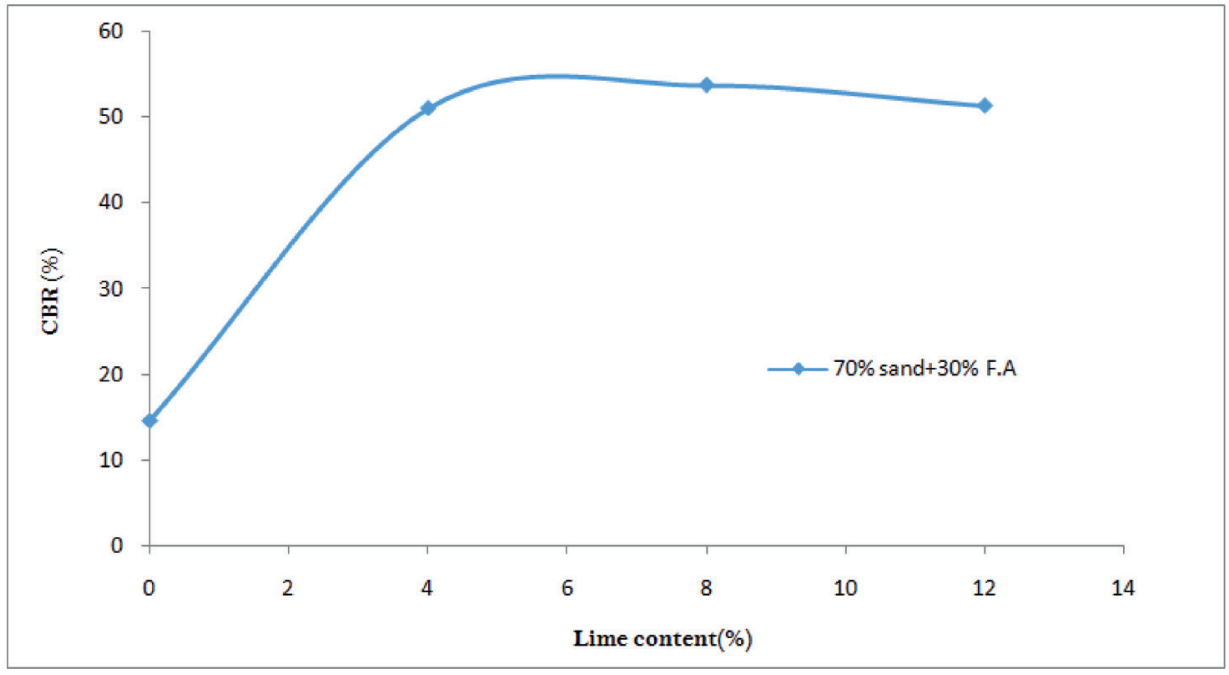

(a)

ISSN No.: 2321-3906 (Print) ISSN No.: 2321-7146 (Online) Registration No.: CHAENG/201/51235

Periodicity: Bi-Annually 


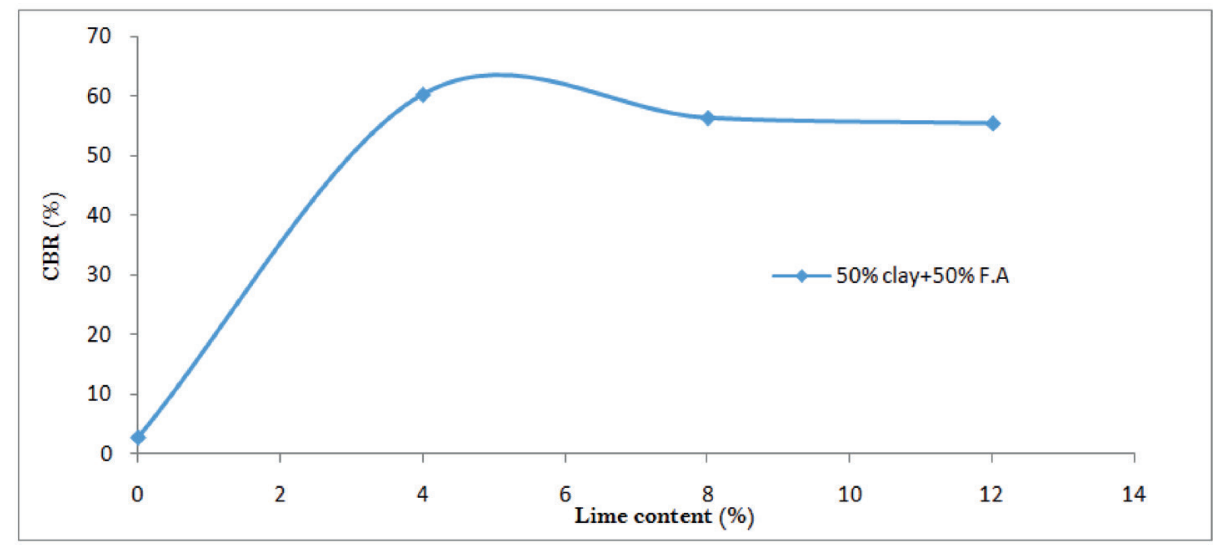

(b)

Figure 6: Variation of soaked C.B.R of $70 \%$ sand $+30 \%$ fly ash (a) and $50 \%$ clay $+50 \%$ fly ash (b) with lime content.

\section{Conclusion}

Proctor compaction results of locally available soil with fly ash mix showed that MDD value directly proportional to fly ash content up to an optimum fly ash content of 40-60\%. Similarly MDD value of local sand showed increases with increase of fly ash content up to an optimum fly ash content of $20-40 \%$, thereafter increase in fly ash content showed a decrease of MDD value. UU Triaxial test showed increased cohesion of both locally available soil and local sand with fly ash mixtures with increased lime content. The cohesion value also increased with increased curing time of the sample. Soaked CBR test showed drastic increase in CBR value of both locally available soil and local sand with fly ash mixture by increase in lime in the range of $5-6 \%$.

Based on the test results presented in tables and graphs, the following conclusions have been drawn:

1. Fly ash percentage in the range $40-60 \%$ can be satisfactorily used to replace the local clayey soil for the improvement of the subgrade. Similarly, fly ash content within
$20-40 \%$ can be used to replace the local sand for the improvement of the subgrade.

2. Fly ash has no swelling property and also it is widely available from thermal power plant at a minimum cost. So it can be recommended that fly ash be utilized as supplementary and alternative material for construction of pavement which can replace the percentage of sand and clay for construction of embankment for a pavement.

3. An exponential correlation between hydraulic conductivity and maximum dry density (MDD) of soil mixed with varied percentage of fly ash has been found out. For that particular percentage of soil (sand / clay) with fly ash content; when MDD was maximum hydraulic conductivity has been found minimum.

4. Lime content in the range of $4-8 \%$ can be satisfactorily used in both clay and local sand with fly ash mixtures for improvement of strength in terms of shear strength as well as CBR value.

5. Increased curing time of fly ash-soillime and sand-fly ash-lime mixtures showed increase in shear strength. 
6. The shear strength of specimens under soaked condition were greater than that of unsoaked condition in addition of lime with increasing the curing time.

\section{Acknowledgments}

The authors would like to thank Department of Civil Engineering, Techno India University, West Bengal and University of Engineering \& Management (UEM), Kolkata for providing permission and utilizing the laboratory facilities for performing all the laboratory tests.

\section{References}

[1] AASHTO: "Standard method of test for resilient modulus of subgrade soils and untreated base/sub-base materials," Guide for design of pavement structures, Washington, DC., T292, 1993.

[2] N. S. Pandian, K.C. Krishna and B. Leelavathamma, "Effect of fly ash on the CBR behaviour of soils," Indian Geotechnical Conference, Allahabad, vol.1, pp. 183-186, 2002.

[3] A. Misra, D. Biswas and S. Upadhyaya, "Physico-mechanical behavior of self-cementing class C fly ash-clay mixtures," Fuel 84, pp. 1410-1422, 2005.

[4] V. Kumar, "Fly ash utilization: A mission mode approach ash ponds and ash disposal systems," Narosa Publishing House, New Delhi, India, 1996.

[5] S. Chand and C. Subbarao, "Strength and slake durability of lime stabilized pond ash," Journal of Materials in Civil Engineering, vol. 19, no. 7, pp. 601-608, 2007.

[6] R. Bairwa, A.K. Saxena, T.R. Arora, "Effect of lime and fly ash on engineering properties of black cotton soil," International Journal of Emerging
Technology and Advanced Engineering, vol. 3, no. 11, 2013.

[7] D. Kumar, A. Gupta and N. Kumar, "Some geotechnical properties of coal fly ash and sand mixtures with different ratio using in highway \& embankments," Global Journal of Researches in Engineering, vol. 14, no. 5, 2014.

[8] C.R.V. Prasad and R. K. Sharma, "Influence of sand and fly ash on clayey soil stabilization,” IOSR Journal of Mechanical and Civil Engineering, pp. 36-40, 2014.

[9] K. Harichane, M. Ghrici and S. Kenai, "Effect of curing time on shear strength of cohesive soils stabilized with combination of lime and natural pozzolana," International Journal of Civil Engineering, vol. 9, pp. 90-96, 2010.

[10] C. K. Shen and S. K. Li, "Lime stabilization of clay-sand mixtures," Highway Research Record No. 315, Highway Research Board, 1970.

[11] B. Kim, M. Prezzi, and R. Salgado, "Geotechnical properties of fly ash and bottom ash mixtures for use in highway embankments," Journal of Geotechnical and Geoenvironmental Engineering, vol. 131, no. 7, pp. 914-924, 2005.

[12] T. B. Edil, H. A. Acosta, and C.H. Benson, "Stabilizing soft fine-grained soils with fly ash," Journal of Materials in Civil Engineering, vol. 18, no. 2, pp. 283-294, 2006.

[13] E.O. Tastan, T.B. Edil, C.H. Benson and A.H. Aydilek, "Stabilization of organic soils with fly ash," Journal of Geotechnical and Geoenvironmental Engineering, pp. 819-833, 2011.

[14] IS 1498: Classification and identification of soils for general engineering purposes, 1970.

[15] IS 2720-3-1: Methods of test for soils, 
Part 3: Determination of specific gravity, Section 1: Fine grained soils, 1980.

[16] IS 2720-3-2: Methods of test for soils, Part 3: Determination of specific gravity, Section 2: Fine, medium and coarse grained soils, 1980 .

[17] IS 2720-4: Methods of test for soils, Part 4: Grain size analysis, 1985.

[18] IS 2720-5: Methods of test for soils, Part 5: Determination of liquid and plastic limit, 1985.

[19] IS 2720-7: Methods of test for soils, Part 7: Determination of water content-dry density relation using light compaction, 1980.

[20] IS 2720-11: Methods of test for soils, Part 11: Determination of the shear strength parameters of a specimen tested in unconsolidated undrained triaxial compression without the measurement of pore water pressure, 1993.

[21] IS 2720-16: Methods of test for soils, Part 16: Laboratory determination of CBR, 1987.

[22] IS 2720-17: Methods of test for soils, Part 17: Laboratory determination of permeability, 1986. 


\section{旬}

\section{Journal on Today's Ideas - Tomorrow's Technologies}

CHITKARA

UNIVERSITY

Chitkara University, Saraswati Kendra, SCO 160-161, Sector 9-C,

Chandigarh, 160009, India

Volume - 7 , Issue-2

December 2019

ISSN 2321-3906

Copyright: [C 2019 Pinak Ray, Subham Roy \& Alekhya Sarkar] This is an Open Access article published in Journal on Today's Ideas - Tomorrow's Technologies by Chitkara University Publications. It is published with a Creative Commons Attribution- CC-BY 4.0 International License. This license permits unrestricted use, distribution, and reproduction in any medium, provided the original author and source are credited. 